\title{
Valentini Scleroderma Disease Activity Index
}

National Cancer Institute

\section{Source}

National Cancer Institute. Valentini Scleroderma Disease Activity Index. NCI Thesaurus.

Code C121364.

A clinical index used to assess the activity of scleroderma that has been validated in adults. 